\title{
Exogenous FABP4 increases breast cancer cell proliferation and activates the expression of fatty acid transport proteins.
}

\begin{tabular}{|c|c|}
\hline Journal: & Molecular Carcinogenesis \\
\hline Manuscript ID & MC-15-0403 \\
\hline Wiley - Manuscript type: & Research Article \\
\hline Date Submitted by the Author: & 02-Dec-2015 \\
\hline Complete List of Authors: & $\begin{array}{l}\text { Guaita-Esterurelas, Sandra; Institut d'Investigació Sanitària Pere Virgili; } \\
\text { Universitat Rovira i Virgili, Medicine and Surgery; "Sant Joan" University } \\
\text { Hospital, Oncology Institute of Southern Catalonia (IOCS) } \\
\text { Bosquet, Alba; Institut d'investigació Sanitària Pere Virgili; Universitat } \\
\text { Rovira i Virgili, Medicine and Surgery } \\
\text { Saavedra, Paula; Universitat Rovira i Virgili, Medicine and Surgery } \\
\text { Gumà, Josep; "Sant Joan" University Hospital, Oncology Institute of } \\
\text { Southern Catalonia (IOCS) } \\
\text { Girona, Josefa; Univeristat Rovira i Virgili, Medicine and Surgery } \\
\text { Lam, Eric ; Imperial Centre for Translational and Experimental Medicine } \\
\text { (ICTEM), Imperial College London, Department of Surgery and Cancer } \\
\text { Amillano, Kepa; "Sant Joan" University Hospital, Oncology Institute of } \\
\text { Southern Catalonia (IOCS) } \\
\text { Borràs, Joan; "Sant Joan" University Hospital, Oncology Institute of } \\
\text { Southern Catalonia (IOCS) } \\
\text { Masana, Lluís; Universitat Rovira i Virgili, Medicine and Surgery }\end{array}$ \\
\hline Keywords: & $\begin{array}{l}\text { Fatty acid binding protein } 4 \text {, Breast cancer, Lipid metabolism, Fatty acid } \\
\text { transport proteins, Proliferation }\end{array}$ \\
\hline
\end{tabular}


Title: Exogenous FABP4 increases breast cancer cell proliferation and activates the expression of fatty acid transport proteins.

Guaita-Esteruelas S. ${ }^{* 1,2,3}$, Bosquet A. ${ }^{1,2}$, Saavedra P. ${ }^{2}$, Gumà J. ${ }^{3}$, Girona J. ${ }^{2}$, Lam E.W.-F. ${ }^{4}$, Amillano K. ${ }^{3}$, Borràs $J^{3}{ }^{3}$ and Masana $L^{2}$.

${ }^{*}$ Corresponding author.

1. Institut d'Investigació Sanitària Pere Virgili (IISPV). Centre $d^{\prime} R+D+l$ en Nutrició $i$ Salut. Avda. de la Universitat, 43204 Reus, Spain

2. Research Unit on Lipids and Atherosclerosis. Universitat Rovira i Virgili. Sant Llorenç, 2143201 Reus, Spain.

3. Oncology Research group, "Sant Joan" University Hospital, Oncology Institute of Southern Catalonia (IOCS), Av. del Dr. Josep Laporte, 2, 43204 Reus, Spain.

4. Department of Surgery and Cancer, Imperial Centre for Translational and Experimental Medicine (ICTEM), Imperial College London. Du Cane Road, London W12 ONN, UK

${ }^{*}$ Corresponding author. Guaita-Esteruelas S.

e-mail:sandra.guaita@urv.cat

Sant Llorenç, 21 street.

\begin{abstract}
Adipose tissue plays an important role in tumour progression, through providing nutrients and adipokines to proliferating cells. FABP4 (Fatty acid binding protein 4) is a key adipokine for fatty acid transport. In metabolic pathologies, FABP4 plasma levels are increased. Despite this, the role of the circulating protein is unknown. Recent studies have demonstrated that FABP4 might have a role in tumour progression, but the molecular mechanisms involved are still unclear. In this study, we analysed the role of eFABP4 (exogenous FABP4) in breast cancer progression. MCF-7 and MDA-MB231 breast cancer cells did not express substantial FABP4 protein, but intracellular FABP4 levels increased after eFABP4 incubation. Moreover, eFABP4 enhanced the
\end{abstract}


proliferation of these breast cancer cells but did not have any effect on MCF-7 and MDA-MB-231 cell migration. Furthermore, eFABP4 increased cell viability in MDA-MB231 cells and decreased cell cytotoxicity in MCF-7 cells. Additionally, eFABP4 induced the AKT and MAPK signalling cascades in breast cancer cells, and the inhibition of these pathways reduced the cell proliferation induced by eFBAP4. Interestingly, eFABP4 increased the levels of the FoxM1 transcription factor and the fatty acid transport proteins CD36 and FABP5 in MCF-7 cells. In summary, we showed that eFABP4 plays a key role in tumour proliferation and activates the expression of fatty acid transport proteins in MCF-7 breast cancer cells.

\section{Introduction}

Breast cancer is the most frequent malignancy in women and the second leading cause of cancer-related deaths [1].Epidemiologic studies have indicated that obesity is associated with a higher risk of certain cancers, including postmenopausal breast cancer. This positive association may be partly explained by insulin resistance, hyperinsulinemia, sustained hyperglycaemia, glucose intolerance, oxidative stress and inflammation. Emerging research has also begun to focus on the role of circulating adipokines (i.e., adipocyte secreted factors) in breast cancer [2-4] Moreover, patients with metabolic syndrome and diabetes are at increased risk of developing postmenopausal breast cancer $[5,6]$.

FABP4 (Fatty Acid Binding Protein 4) is an adipokine that transports fatty acids to various cellular compartments to exert their metabolic functions $[7,8]$. FABP4 is implicated in several critical cellular processes, such as the uptake and intracellular storage of fatty acids and the regulation of gene expression, cell proliferation, and differentiation [7].

FABP4 has gained increasing interest in recent years because we and others identified circulating FABP4 as a metabolic and vascular risk biomarker. FABP4 is released from adipocytes and macrophages and is present in human blood. High levels of this protein 
are associated with some metabolic diseases, such as obesity, metabolic syndrome, type 2 diabetes and atherosclerosis, making FABP4 a good prognostic marker in the plasma for these pathologies [9-17]. Moreover, we have described that eFABP4 is involved in the control of proliferation and migration of human smooth muscle cells from the coronary artery [18].

While FABP4 was initially described in adipocytes and macrophages, current evidence has demonstrated its expression in different cell types and some tumours [19-21]. FABP4 has an increasingly important role in tumour progression, but few studies have explored the relationship between FABP4 and breast cancer. FABP4 has been described as a new prognostic factor in bladder cancer, in residual disease of ovarian cancer and in obese patients with breast cancer [22-24]. Moreover, FABP4 is overexpressed in glioblastoma and could have a pro-angiogenic role, being regulated by VEGF and bFGF $[20,21]$.

FABP4 is a mediator of interactions between bone marrow adipocytes and prostate tumour cells [25]. Exogenous FABP4 (eFABP4) promotes tumour progression in prostate cancer [26]. Finally, FABP4 is a key protein in the migration of ovarian cancer cells and is a very good target protein for the prevention or treatment of some types of cancer [19].

While much effort has been focused on uncovering the role of FABP4 in recent years, the role of eFABP4 in breast cancer is still unknown. The objective of this study is to analyse the role of eFABP4 in breast cancer progression.

\section{Results}

\section{eFABP4 is internalized by breast cancer cells}

We demonstrated previously that eFABP4 is internalized in different cell line models $[18,27]$. Here, we examined the role of eFABP4 in breast cancer. First, we analysed the expression of FABP4 in MCF-7 and MDA-MB-231 cells. These breast cancer cells did 
not express FABP4 protein at considerable levels (Fig 1a). Next, we assessed whether eFABP4 is internalized by breast cancer cells. We added $100 \mathrm{ng} / \mathrm{ml}$ of recombinant eFABP4 in the culture medium, and we detected eFABP4 expression by western blot (Fig 1a; 36.79-fold increase in MCF-7 cells, $p<0.0001 ; 19.13$-fold increase in MDA-MB231 cells, $p=0.0002$ vs unstimulated cells) and immunofluorescence (Fig 1b, $100 \%$ in MCF-7 and $85.14 \%$ in MDA-MB-231 cells, ${ }^{* *} p<0.005$ vs unstimulated cells). These results showed that eFABP4 is internalized in MCF-7 and MDA-MB-231 cells.

\section{eFABP4 induces breast cancer cell proliferation}

After demonstrating that eFABP4 is internalized by breast cancer cells, we investigated whether eFABP4 induces breast cancer cell proliferation. A cell proliferation assay by BrdU incorporation was performed. We observed that eFABP4 increased breast cancer cell proliferation in a dose-dependent manner (Fig 2a and 2b). eFABP4 treatment (20$100 \mathrm{ng} / \mathrm{ml})$ significantly $\left({ }^{* * *} \mathrm{p}<0.0001\right)$ increased BrdU incorporation in MCF-7 cells compared with untreated MCF-7 cells. Moreover, $100 \mathrm{ng} / \mathrm{ml}$ of eFABP4 induced an increase in BrdU incorporation in MDA-MB-231 ( $\left.{ }^{*} p=0.0169\right)$ vs untreated MDA-MB231 cells, but lower concentrations of eFABP4 did not have this effect. eFABP4 induced MCF-7 and MDA-MB-231 cell proliferation.

Next, we analysed the effect of eFABP4 on breast cancer cell migration by woundhealing assay. However, eFABP4 treatment $(20-100 \mathrm{ng} / \mathrm{ml})$ did not have any effect on MCF-7 and MDA-MB-231 cell migration at any time (6 $\mathrm{h}$ and $24 \mathrm{~h}$ ) (Fig $3 \mathrm{a}$ and $3 \mathrm{~b}$ ), suggesting that eFABP4 does not have any effect on breast cancer cell migration.

Moreover, we also determined the effect of eFABP4 on cell cytotoxicity and viability. To define cell cytotoxicity, we used an LDH detection kit. We observed a significant reduction in LDH secretion at $48 \mathrm{~h}$ after eFABP4 treatment $(100 \mathrm{ng} / \mathrm{ml})$ in MCF-7 cells. On the other hand, when we examined the effect of eFABP4 on cell viability, we observed a significant increase in cell viability in MDA-MB-231 cells at $48 \mathrm{~h}$ after 
eFABP4 treatment $(100 \mathrm{ng} / \mathrm{ml})$ (Fig $4 \mathrm{a}$ and $4 \mathrm{~b} ;{ }^{*} \mathrm{p}<0.05$ vs untreated cells). Thus, eFABP4 slightly increases cell viability in MDA-MB-231 cells and reduces cell cytotoxicity in MCF-7 cells.

\section{eFABP4 induces the AKT and MAPK pathways in breast cancer cells}

The MAPK and AKT pathways play an important role in cancer progression, so we analysed the role of eFABP4 in MAPK and AKT activation. After 5-15 min of eFABP4 treatment $(100 \mathrm{ng} / \mathrm{ml})$, we observed phosphorylation of ERK and AKT proteins (Fig 5a and 5b; 3.09-fold increase in AKT and 4.31-fold increase in MAPK in MCF-7 cells; 2.80-fold increase in AKT and 1.67-fold increase in MAPK in MDA-MB-231 cells; ${ }^{*} p<0.05$ and ${ }^{* *} p<0.005$ vs. unstimulated cells), indicative of their activation.

As shown above, eFABP4 induced cell proliferation in breast cancer cells. Therefore, we analysed whether this induction is mediated by the MAPK and AKT pathways. We performed proliferation experiments with eFABP4 in the presence or absence of the PI3K/AKT (LY-294002, $5 \mu \mathrm{M})$ or MAPK (PD98059, $10 \mu \mathrm{M})$ inhibitors. eFABP4 was unable to induce cell proliferation in breast cancer cells in the presence of either PI3K/AKT or MAPK inhibitors (Fig 6a MCF-7 and Fig 6b MDA-MB-231; ${ }^{* * *} p<0.0001$, ${ }^{*} p=0.0169$ and ${ }^{*} p<0.05$ vs untreated cells). Therefore, eFBAP4 mediates cell proliferation by MAPK and AKT pathway activation.

\section{eFABP4 increases the expression of FoxM1 in MCF-7 cells}

FoxM1 is a transcription factor that controls key processes in cancer progression, such as cell proliferation [28]; therefore, we next analysed whether eFABP4 could regulate this transcription factor. After $24 \mathrm{~h}$ of treatment, eFABP4 $(100 \mathrm{ng} / \mathrm{ml})$ increased the expression of FoxM1 protein (Fig 7a; 4.64 -fold increase * $\mathrm{p}=0.028$ vs untreated cells) in MCF-7 cells. In contrast, the levels of FoxM1 in MDA-MB-231 cells did not change significantly (Fig 7b). 


\section{eFABP4 induces the expression of FABP5 and CD36 in MCF-7 cells}

Because fatty acid transport proteins have been implicated in cancer progression [29], we examined whether eFABP4 has any effect on the regulation of other fatty acid transport proteins, such as FABP5 and CD36. To this end, we treated breast cancer cells with $100 \mathrm{ng} / \mathrm{ml}$ of eFABP4 for $24 \mathrm{~h}$, and total cell extracts were analysed for the expression of FABP5 and CD36 by Western blotting. eFABP4 increased FABP5 and CD36 protein levels in MCF-7 cells, but not in MDA-MB-231 cells (Fig 7a and Fig 7b; 1.685-fold increase of FABP5 and 27.03-fold increase of CD36; ${ }^{* * *} \mathrm{p}<0.0001$, ${ }^{* * *}$ $p=0.0001$ and ${ }^{*} p<0.05$ vs untreated cells). Moreover, MCF-7 and MDA-MB-231 cells were incubated with eFABP4 for $24 \mathrm{~h}$, and immunofluorescence staining with antiFABP5 and anti-CD36 was performed. Immunofluorescence images showed an increased presence of FABP5 and CD36 in MCF-7 cells that were incubated with eFABP4 compared to control cells, but no changes were found in MDA-MB-231 cells (Fig 7c and Fig $7 e^{* * * *} p<0.0001$ and ${ }^{*} p<0.05$ vs untreated cells for MCF-7 cells and Fig 7d and Fig 7e for MDA-MB-231 cells). Therefore, lipid metabolism-related proteins are differentially expressed and regulated in these breast cancer cell lines.

\section{Discussion}

Adipocytes are active and important modulators of the tumour microenvironment by direct contact with neighbouring cells or by secreted adipokines [25]. In this manner, the role of some adipokines in cancer has been established [30]. Recent studies have demonstrated that autocrine, endocrine, and paracrine adipokines may contribute to the regulation of breast cancer development and progression [31,32].

FABP4 is a fatty acid transport protein implicated in some metabolic disorders. Moreover, FABP4 has been implicated in cancer cell growth and metastasis [33,34]. Despite this data, little is known about the role of FABP4 in breast cancer. In this study, we examined the role of eFABP4 in breast cancer progression. 
Previously, we and others have described increased levels of circulating FABP4 in individuals with some metabolic diseases. Moreover, FABP4 has a direct effect on peripheral tissues and can interact with the plasma membrane by CK1 [27]. These previous results demonstrated that circulating FABP4 is not simply a biomarker but that it may have a causal function by interacting with other cell types.

To define the role of eFABP4 in breast cancer progression, we assessed whether eFABP4 is internalized by breast cancer cells. Our results demonstrated that eFABP4 was internalized in MCF-7 and MDA-MB-231 cells (Fig 1). These results agree with Uehara et al 2014 and our previous data [18,27], reinforcing the idea that eFABP4 could have a central role in breast cancer cells, while FABP4 is not highly expressed in these breast cancer cells.

Next, we analysed the role of eFABP4 in cell proliferation and migration. We found that eFABP4 increased cell proliferation but not cell migration in MCF-7 and MDA-MB-231 cells (Fig 2 and Fig 3). In fact, cell proliferation was affected in a dose-dependent manner. BrdU incorporation was increased with 20 to $100 \mathrm{ng} / \mathrm{ml}$ eFABP4 in MCF-7 cells with $100 \mathrm{ng} / \mathrm{ml}$ eFABP4 in MDA-MB-231 cells. These concentrations are physiologically relevant because Hancke et al 2010 [24] described serum FABP4 levels of $41.16 \mathrm{ng} / \mathrm{ml}$ in obese $(\mathrm{BMI}>25)$ and $24.95 \mathrm{ng} / \mathrm{ml}$ in non-obese women (BMI < 24.9). Importantly, there is a significant difference between the 20 and $100 \mathrm{ng} / \mathrm{ml}$ eFABP4 results $(p<0.001)$, hinting to the importance of the presence of the protein and the concentration as well.

Cell growth can be promoted by activation of a signalling network that induces pathways that are mediated by phosphoinositide 3-kinase (PI3K-AKT) and extracellular signalling kinase (MAPK-ERK). For this reason, we analysed whether eFABP4 can activate these two pathways. eFABP4 induced AKT and MAPK pathway activation defined by the detection of phospho-AKT $\left(\mathrm{Ser}^{473}\right)$ and phospho-p42/p44 $\left(\mathrm{Thr}^{202} / \mathrm{Tyr}^{204}\right)$ 
(Fig 5). Therefore, eFABP4 induces cell proliferation by activating these two key pathways.

The FOXM1 transcription factor has a central function in cell cycle progression and cell proliferation. Moreover, FOXM1 overexpression has been identified in many types of cancers, including breast cancer. In addition, there is also a key role for FOXM1 in tumorigenesis, cancer progression and drug resistance [28]. We assessed whether eFABP4 has any role in FOXM1 regulation; $100 \mathrm{ng} / \mathrm{ml}$ of eFABP4 induced FOXM1 expression in MCF-7 cells but did not have any effect in MDA-MB-231 cells. Thus, eFABP4 can regulate cancer cell proliferation by different mechanisms: the activation of PI3K-AKT and MAPK-ERK pathways and the induction of FOXM1 expression in MCF-7 cells.

Several proteins have been identified to facilitate the uptake of fatty acids into cells, and these proteins are deregulated in some cancers, such as breast cancer [29]. Accordingly, we analysed whether eFABP4 is able to induce the expression of other fatty acid transport proteins. We described that eFABP4 increased the levels of CD36 and FABP5 in MCF-7 cells but not in MDA-MB-231 cells. MCF-7 and MDA-MB-231 breast cancer cells have differences in the regulation of lipid metabolism pathways [35]. Therefore, lipid metabolism-related proteins are differentially expressed and regulated in these breast cancer cell lines.

The role of FABP4 in some tumours has been described previously, but in this paper, we described a new role for eFABP4 in breast cancer. Adipose tissue has a crucial role in breast cancer development. In fact, some adipokines from this tissue have been implicated in breast cancer progression [2-4]. Now, we describe the role of eFABP4 in breast cancer progression, emphasising the role of eFABP4 in cell proliferation and regulation of expression of fatty acid transport proteins. FABP4 could have three roles in the control of breast cancer development: 1) FABP4 could induce angiogenesis in 
breast cancer tissue, as has been shown in glioblastoma [20,21]; 2) FABP4 could be over-expressed in breast cancer tissue [36], even though other authors have described the opposite expression [37]; and 3) eFABP4 from surrounding adipose tissue could have a central role in cancer progression, as we have described in this paper, and Nieman et al 2011, Uehara et al 2014 and Mauro et al 2015 previously described in ovarian and prostate cancer [19,26,31]. Moreover, the majority of FABP4 in circulation is generated from the stromal compartment [38], so the adipose tissue could have a central role in breast cancer progression.

Finally, the cross-talk between adipokines/adipose tissue and breast cancer tissue should be reciprocal. Breast cancer cells could induce fatty acid and adipokine mobilization from adipose tissue. This process could be through the control of FABP4 secretion in adipose tissue by regulating the lipolysis secretory pathway [39] or the calcium-dependent secretion mechanism [40]. Moreover, interestingly, increased FABP4 release from adipose tissue has been observed in adipocytes exposed to hypoxia [41]. This condition is frequently found in tumour tissue and adipose tissue in obesity.

In summary, we described a novel role for eFABP4 in breast cancer progression. eFABP4 induces breast cancer cell proliferation by activating the PI3K-AKT and MAPK-ERK pathways. Moreover, in MCF-7 cells, eFABP4 induces the expression of the potent oncogene FOXM1 and fatty acid transport proteins CD36 and FABP5.

Thus, FABP4 might act as a paracrine adipokine and might be one of the key molecules to understand the mechanisms underlying the obesity-breast cancer progression link and the cross-talk between cancer cells and adipose tissue in nonobese patients.

\section{Figures}


Figure 1. eFABP4 is internalized by breast cancer cells. MCF-7 and MDA-MB-231 (231) cells were treated with $100 \mathrm{ng} / \mathrm{ml}$ of eFABP4 (eF100). After $24 \mathrm{~h}$, the cells were lysed with $2 \%$ SDS buffer, and western blot (Fig 1a) or immunofluorescence (Fig 1b) was performed. The results are expressed as the mean \pm SEM of three independent experiments. ${ }^{* * * *} P<0.0001$ and ${ }^{* * *} p=0.0002$ vs untreated cells.

Figure 2. Effect of eFABP4 on the proliferation of breast cancer cells. Effect of eFABP4 (20-100 ng/ml) on the proliferation of MCF-7 (Fig 2a) and MDA-MB-231 (Fig 2b) cells was assessed by BrdU incorporation. The results are expressed as the mean \pm SEM of three independent experiments run in quintuplicate. ${ }^{* \star * *} p<0.0001,{ }^{* * *} p<0.0002$ and ${ }^{*} p=0.0169$ vs untreated cells.

Figure 3. Effect of eFABP4 on the migration of breast cancer cells. After reaching confluence, MCF-7 and MDA-MB-231 cells were treated with eFABP4 (20-100 ng/ml) at different times. A wound-healing assay was performed, and the $\%$ of migration was measured in MCF-7 (Fig 3a) and MDA-MB-231 (Fig 3b) cells. The results are expressed as the mean \pm SEM of three independent experiments run in quintuplicate.

Figure 4. Effect of eFABP4 on cytotoxicity and cell viability of breast cancer cells. Effect of eFABP4 (100 ng/ml) on cytotoxicity was assessed using an LDH detection kit at $24 \mathrm{~h}$ and $48 \mathrm{~h}$. Moreover, the effect of eFABP4 $(100 \mathrm{ng} / \mathrm{ml})$ on cell viability was assessed using the Cell Titer Glo Detection Kit at the same times. Cytotoxicity (Fig 4a) and cell viability (Fig 4b) were measured in MCF-7 and MDA-MB-231 cells. The results are expressed as the mean \pm SEM of three independent experiments run in triplicate $\left({ }^{*} p<0.05\right)$.

Figure 5. Effect of eFABP4 on the AKT and MAPK pathways in breast cancer cells. The effect of eFABP4 (100 ng/ml) on the AKT (Fig 5a. MCF-7 left, MDA-MB-231 right) and MAPK (Fig 5b. MCF-7 left, MDA-MB-231 right) pathways was assessed by western blot at short times. Representative western blots and relative densitometric 
analyses are shown. The results are expressed as the mean \pm SEM of three independent experiments. ${ }^{*} p<0.05$ and ${ }^{* *} p<0.005$ vs. unstimulated cells (control).

Figure 6. Effect of AKT and MAPK pathway inhibition on eFAPB4 cell proliferation induction in breast cancer cells. AKT (LY-294002, $5 \mu \mathrm{M})$ and MAPK (PD98059, $10 \mu \mathrm{M})$ inhibitors were added to breast cancer cells to assess the pathways activated upon eFABP4 $(100 \mathrm{ng} / \mathrm{ml})$ treatment. BrdU incorporation was analysed. The results are expressed as the mean \pm SEM of three independent experiments. ${ }^{* * * *} p<0.0001$, ${ }^{*} p=0.0169$ and $\# p<0.05$ vs untreated cells.

Figure 7. Regulation of the expression of fatty acid transport proteins by eFABP4. MCF-7 and MDA-MB-231 (231) cells were treated with $100 \mathrm{ng} / \mathrm{ml}$ of eFABP4 (eF100). After $24 \mathrm{~h}$, the cells were lysed with $2 \%$ SDS buffer, and western blot (Fig $7 \mathrm{a}$ and Fig $7 b ;{ }^{* * *} p<0.0001,{ }^{* * *} p=0.0001$ and ${ }^{*} p<0.05$ vs untreated cells) or immunofluorescence (Fig 7c-MCF-7 cells, 7d-MDA-MB-231 cells and $7 e$; ${ }^{* * * *} p<0.0001$ and ${ }^{*} p<0.05$ vs untreated cells) was performed. The results are expressed as the mean \pm SEM of three independent experiments.

\section{MATERIALS AND METHODS}

\section{Cell culture and reagents}

Human MCF-7 and MDA-MB-231 breast cancer cells were kindly provided by Professor Eric W. Lam (Department of Surgery and Cancer, Imperial College London, Hammersmith Hospital Campus, London, UK). The cells were cultured in Dulbecco's modified Eagle's medium (DMEM) supplemented with $10 \%$ foetal calf serum, $1 \mathrm{mM}$ glutamine, $1 \mathrm{mM}$ penicillin-streptomycin and $1 \mathrm{mM}$ NEAA (Biowest, Nuaillé, France) in a humidified incubator at $37^{\circ} \mathrm{C}$ with $5 \% \mathrm{CO}_{2}$. Before the initiation of the assays, the cells were changed into DMEM supplemented with $0.1 \%$ FBS for $24 \mathrm{~h}$. 
MCF-7 and MDA-MB-231 cells were treated with increasing concentrations (20, 40 and $100 \mathrm{ng} / \mathrm{ml}$ ) of recombinant FABP4 (eFABP4) (Biovendor, Brno, Czech Republic) for 24 h. To study the activation of proliferation pathways in these cells, the PI3K inhibitor LY294002 $(5 \mu \mathrm{M})$ and the MAPK inhibitor PD98059 $(10 \mu \mathrm{M})$ (Calbiochem-Merck, Darmstadt, Germany) were used.

\section{Western blotting}

MCF-7 and MDA-MB-231 cells were lysed in $2 \%$ SDS buffer $(2 \%$ SDS and $67 \mathrm{mmol} / \mathrm{l}$ Tris $\mathrm{HCl} \mathrm{pH} \mathrm{6.8).} \mathrm{Protein} \mathrm{concentrations} \mathrm{were} \mathrm{determined} \mathrm{using} \mathrm{the} \mathrm{Lowry} \mathrm{assay.} \mathrm{Thirty}$ micrograms of total protein were separated on $10 \%$ SDS-PAGE gels and transferred to nitrocellulose membranes using an iBlot $\AA$ Dry Blotting System (Life Technologies, Madrid, Spain). Antibodies against AKT, pAKT (Ser473), p44/p42 MAPK (Erk1/2), pp44/p42 MAPK (Erk1/2) (Thr202/Tyr204) and GAPDH were obtained from Cell Signalling Technology, Inc. (Beverly, MA, USA). The FOXM1 (C-20) antibody was obtained from Santa Cruz Biotechnology (Dallas, Texas, USA). The FABP5 antibody was obtained from (R\&D Systems, Inc., Minneapolis, USA). The CD36 antibody was obtained from (Abcam plc, Cambridge, UK). Membranes were incubated with the appropriate HRP-conjugated secondary antibody (Dako, Glostrup, Denmark). The bands were visualized using ECL reagents (GE Healthcare Europe GmbH, Barcelona, Spain) with the ChemiDoc image system and quantified with Image Lab software, version 5.2 (Bio-Rad, USA). The ratio of target proteins to GAPDH was used to reflect the relative levels of the target proteins.

\section{Immunofluorescence microscopy}

MCF-7 and MDA-MB-231 cells were incubated in chambered slides (Nunc, Roskilde, Denmark) with or without eFABP4 $(100 \mathrm{ng} / \mathrm{ml})$ for $24 \mathrm{~h}$, fixed with $4 \%$ paraformaldehyde (Sigma-Aldrich, USA) for $15 \mathrm{~min}$ at room temperature and washed at each step three times with DPBS $(\mathrm{GIBCO} \otimes$, Life Technologies, Alcobendas-Madrid, 
Spain). The cells were permeabilized after fixation with a solution containing DPBS, $2 \%$ FBS, $0.1 \%$ BSA, and $0.1 \%$ Triton $\mathrm{X}-100$ for $5 \mathrm{~min}$ at RT. Then, blocking solution was added for $20 \mathrm{~min}$ at $\mathrm{RT}$. The cells were incubated for $1 \mathrm{~h}$ at $37^{\circ} \mathrm{C}$ with FABP4, FABP5 and CD36 antibodies and further incubated with Alexa Fluor ${ }^{\circledR} 488$ anti-goat and rhodamine anti-mouse antibodies (Invitrogen Life Technologies, Alcobendas-Madrid, Spain) for $1 \mathrm{~h}$ at RT. The antibodies were diluted in blocking solution (DPBS, $2 \%$ FBS, and $0.1 \%$ BSA). The cells were incubated with the nuclear stain DAPI (4',6-diamidino2-phenylindole, dilactate) (Life Technologies, Alcobendas-Madrid, Spain) for $5 \mathrm{~min}$. Immunofluorescence images were captured with an Olympus IX71 inverted microscope, processed with Cell^F Software (Olympus, Shinjuku-ku, Tokyo, Japan) and quantified with ImageJ (Fiji, Madison, WI, USA).

\section{Cell proliferation studies}

The cell proliferation assay was performed with a colorimetric bromodeoxyuridine (BrdU) enzyme-linked immunosorbent assay (ELISA) kit (Roche Diagnostics, Basel, Switzerland), according to the manufacturer's instructions. Briefly, 10,000 cells were seeded into a 96-well microplate and cultured with increasing concentrations of eFABP4 (20-200 ng/ml) and LY294002 (5 $\mu \mathrm{M})$ or PD98059 $(10 \mu \mathrm{M})$ for $24 \mathrm{~h}$. The cells were labelled with BrdU labelling reagent overnight. After fixation, the cells were incubated with an anti-BrdU antibody for $90 \mathrm{~min}$. Finally, $100 \mu \mathrm{l}$ of substrate (tetramethylbenzidine) was added to each well, and the plates were incubated at room temperature for $30 \mathrm{~min}$. The absorbance at $450 \mathrm{~nm}$ was measured with an ELISA reader (Synergy H4, Biotek, USA).

\section{In vitro wound-healing assay}

MCF-7 and MDA-MB-231 cells were cultured in 12-well plates until they reached confluence. Then, the cells were maintained for $24 \mathrm{~h}$ in $0.1 \%$ FBS medium. A single scratch wound was created in the centre of the cell monolayer by gently removing the 
attached cells with a sterile plastic pipette tip. The cells were incubated with eFABP4 (20-200 $\mathrm{ng} / \mathrm{ml})$, and images were taken at $0 \mathrm{~h}$ and then every $2 \mathrm{~h}$ until $24 \mathrm{~h}$ of treatment; the images were compared to quantify the migration rate of the cells. The closure of the wound represented $100 \%$ migration. The cell images were captured using a microscope (Olympus IX71, Spain) and analysed using imaging software (Xcell).

\section{Viability analysis}

MCF-7 and MDA-MB-231 cells were seeded at 7,500 cells $/ \mathrm{cm}^{2}$ in $\mathrm{p} 96$ plates. The cells were starved in $0.1 \%$ FBS-containing medium for $24 \mathrm{~h}$ and treated with eFABP4 (20$200 \mathrm{ng} / \mathrm{ml})$. The CellTiter-Glo® Luminescent Cell Viability Assay was performed according the manufacturer's protocol. To determine the number of viable cells in culture, the amount of ATP present was quantitated (Promega Biotech Ibérica, SL., Alcobendas, Madrid).

\section{Cytotoxicity analysis}

MCF-7 and MDA-MB-231 cells were seeded at 10,000 cells $/ \mathrm{cm}^{2}$ in p96 plates. The cells were starved in $0.1 \%$ FBS-containing medium for $24 \mathrm{~h}$ and treated with eFABP4 (20-200 ng/ml). A cytotoxicity assay was performed by analysing LDH release into the medium using the Cytotoxicity Detection Kit (Roche Diagnostics, Roche Diagnostics, Sant Cugat del Valles-Barcelona, Spain).

\section{Statistics}

The results represented the means \pm SEM of at least 3 separate experiments. Differences between the means were determined using a $t$ test (2-tailed). The differences were considered significant at $p<0.05$. GraphPad Prism 6.01 software (GraphPad Software Inc., La Jolla, CA, USA) was used for the statistical analyses. 


\section{Bibliography}

[1] R. Siegel, J. Ma, Z. Zou, A. Jemal, Cancer statistics, 2014, CA. Cancer J. Clin. 64 (2014) 9-29. doi:10.3322/caac.21208.

[2] K. Nimptsch, T. Pischon, Body fatness, related biomarkers and cancer risk: an epidemiological perspective, Horm. Mol. Biol. Clin. Investig. 22 (2015) 39. doi:10.1515/hmbci-2014-0043.

[3] A. Booth, A. Magnuson, J. Fouts, M. Foster, Adipose tissue, obesity and adipokines: role in cancer promotion, Horm. Mol. Biol. Clin. Investig. 21 (2015) 57. doi:10.1515/hmbci-2014-0037.

[4] S. Schmidt, J.M. Monk, L.E. Robinson, M. Mourtzakis, The integrative role of leptin, oestrogen and the insulin family in obesity-associated breast cancer: potential effects of exercise, Obes. Rev. 16 (2015) 473-487. doi:10.1111/obr.12281.

[5] S.T. Perou CM Eisen MB, van de Rijn M, Jeffrey SS, Rees CA, Pollack JR, Ross DT, Johnsen H, Akslen LA, Fluge O, Pergamenschikov A, Williams C, Zhu SX, Lønning PE, Børresen-Dale AL, Brown PO, Botstein D., Molecular portraits of human breast tumours., Nature. 17 (2000) 747-752.

[6] J.A. Foekens, D. Atkins, Y. Zhang, F.C.G.J. Sweep, N. Harbeck, A. Paradiso, et al., Multicenter Validation of a Gene Expression-Based Prognostic Signature in Lymph Node-Negative Primary Breast Cancer, J. Clin. Oncol. 24 (2006) 16651671. doi:10.1200/jco.2005.03.9115.

[7] A.W. Zimmerman, J.H. Veerkamp, New insights into the structure and function of fatty acid-binding proteins, Cell. Mol. Life Sci. C. 59 (2002) 1096-1116. doi:10.1007/s00018-002-8490-y.

[8] A. Vogel Hertzel, D.A. Bernlohr, The Mammalian Fatty Acid-binding Protein 
Multigene Family: Molecular and Genetic Insights into Function, Trends Endocrinol. Metab. 11 (2000) 175-180. doi:http://dx.doi.org/10.1016/S10432760(00)00257-5.

[9] A. Cabré, N. Babio, I. Lázaro, M. Bulló, A. Garcia-Arellano, L. Masana, et al., FABP4 predicts atherogenic dyslipidemia development. The PREDIMED study, Atherosclerosis. 222 (2012) 229-234. doi:http://dx.doi.org/10.1016/j.atherosclerosis.2012.02.003.

[10] A. Cabré, I. Lázaro, J. Girona, J.M. Manzanares, F. Marimón, N. Plana, et al., Plasma Fatty Acid-Binding Protein 4 Increases with Renal Dysfunction in Type 2 Diabetic Patients without Microalbuminuria, Clin. Chem. 54 (2008) 181-187. doi:10.1373/clinchem.2007.094672.

[11] A. Cabré, I. Lázaro, J. Girona, J.M. Manzanares, F. Marimón, N. Plana, et al., Plasma fatty acid binding protein 4 is associated with atherogenic dyslipidemia in diabetes, J. Lipid Res. 49 (2008) 1746-1751. doi:10.1194/jIr.M800102-JLR200.

[12] A. Cabré, I. Lázaro, J. Girona, J.M. Manzanares, F. Marimón, N. Plana, et al., Fatty acid binding protein 4 is increased in metabolic syndrome and with thiazolidinedione treatment in diabetic patients, Atherosclerosis. 195 (2007) e150-e158. doi:http://dx.doi.org/10.1016/j.atherosclerosis.2007.04.045.

[13] G. Aragonès, R. Ferré, I. Lázaro, A. Cabré, N. Plana, J. Merino, et al., Fatty acid-binding protein 4 is associated with endothelial dysfunction in patients with type 2 diabetes, Atherosclerosis. 213 (2010) 329-331. doi:http://dx.doi.org/10.1016/j.atherosclerosis.2010.07.026.

[14] B. Coll, A. Cabre, C. Alonso-Villaverde, I. Lazaro, G. Aragonés, S. Parra, et al., The fatty acid binding protein-4 (FABP4) is a strong biomarker of metabolic syndrome and lipodystrophy in HIV-infected patients, Atherosclerosis. 199 
(2008) 147-153. doi:http://dx.doi.org/10.1016/j.atherosclerosis.2007.09.032.

[15] I. Lázaro, M. Díaz, A. Cabré, L. Masana, L. Ibáñez, Fatty acid-binding protein-4 plasma levels are associated to metabolic abnormalities and response to therapy in girls and young women with androgen excess, Gynecol. Endocrinol. 27 (2011) 935-939. doi:10.3109/09513590.2011.569608.

[16] I. Lázaro, R. Ferré, N. Plana, G. Aragonès, J. Girona, J. Merino, et al., Lifestyle Changes Lower FABP4 Plasma Concentration in Patients With Cardiovascular Risk, Rev. Española Cardiol. (English Version). 65 (2012) 152-157. http://www.revespcardiol.org/en/lifestyle-changes-lower-fabp4plasma/articulo/90092988/.

[17] A. Xu, Y. Wang, J.Y. Xu, D. Stejskal, S. Tam, J. Zhang, et al., Adipocyte Fatty Acid-Binding Protein Is a Plasma Biomarker Closely Associated with Obesity and Metabolic Syndrome, Clin. Chem. 52 (2006) 405-413. doi:10.1373/clinchem.2005.062463.

[18] J. Girona, R. Rosales, N. Plana, P. Saavedra, L. Masana, J.-C. Vallvé, FABP4 Induces Vascular Smooth Muscle Cell Proliferation and Migration through a MAPK-Dependent Pathway, PLoS One. 8 (2013) e81914. doi:10.1371/journal.pone.0081914.

[19] K.H.A. Nieman KM Penicka CV, Ladanyi A, Buell-Gutbrod R, Zillhardt MR, Romero IL, Carey MS, Mills GB, Hotamisligil GS, Yamada SD, Peter ME, Gwin K, Lengyel E., Adipocytes promote ovarian cancer metastasis and provide energy for rapid tumor growth., Nat Med. 30 (2011) 1498-1503.

[20] H. Elmasri, C. Karaaslan, Y. Teper, E. Ghelfi, M. Weng, T.A. Ince, et al., Fatty acid binding protein 4 is a target of VEGF and a regulator of cell proliferation in endothelial cells, FASEB J. 23 (2009) 3865-3873. doi:10.1096/fj.09-134882. 
[21] O. Cataltepe, M.C. Arikan, E. Ghelfi, C. Karaaslan, Y. Ozsurekci, K. Dresser, et al., Fatty acid binding protein 4 is expressed in distinct endothelial and nonendothelial cell populations in glioblastoma, Neuropathol. Appl. Neurobiol. 38 (2012) 400-410. doi:10.1111/j.1365-2990.2011.01237.x.

[22] G. Boiteux, I. Lascombe, E. Roche, M.-L. Plissonnier, A. Clairotte, H. Bittard, et al., A-FABP, a candidate progression marker of human transitional cell carcinoma of the bladder, is differentially regulated by PPAR in urothelial cancer cells, Int. J. Cancer. 124 (2009) 1820-1828. doi:10.1002/ijc.24112.

[23] G.K. Tucker SL Herbrich SM, Unruh AK, Nick AM, Crane EK, Coleman RL, Guenthoer J, Dalton HJ, Wu SY, Rupaimoole R, Lopez-Berestein G, Ozpolat B, Ivan C, Hu W, Baggerly KA, Sood AK., Molecular Biomarkers of Residual Disease after Surgical Debulking of High-Grade Serous Ovarian Cancer., Clin Cancer Res. Apr 22 (2014).

[24] K. Hancke, D. Grubeck, N. Hauser, R. Kreienberg, J.M. Weiss, Adipocyte fatty acid-binding protein as a novel prognostic factor in obese breast cancer patients, Breast Cancer Res. Treat. 119 (2010) 367-377. doi:10.1007/s10549-009-05779.

[25] M. Herroon, E. Rajagurubandara, A.L. Hardaway, K. Powell, A. Turchick, D. Feldmann, et al., Bone marrow adipocytes promote tumor growth in bone via FABP4-dependent mechanisms, 2013. http://www.impactjournals.com/oncotarget/index.php?journal=oncotarget\&amp;p age=article\&amp;op=view\&amp;path\%5B\%5D=1482.

[26] H. Uehara, T. Takahashi, M. Oha, H. Ogawa, K. Izumi, Exogenous fatty acid binding protein 4 promotes human prostate cancer cell progression, Int. J. Cancer. (2014) n/a-n/a. doi:10.1002/ijc.28903. 
[27] P. Saavedra, J. Girona, A. Bosquet, S. Guaita, N. Canela, G. Aragonès, et al., New insights into circulating FABP4: Interaction with cytokeratin 1 on endothelial cell membranes, Biochim. Biophys. Acta - Mol. Cell Res. 1853 (2015) 29662974. doi:http://dx.doi.org/10.1016/j.bbamcr.2015.09.002.

[28] C.-Y. Koo, K.W. Muir, E.W.F. Lam, FOXM1: From cancer initiation to progression and treatment, Biochim. Biophys. Acta - Gene Regul. Mech. 1819 (2012) 28-37. doi:http://dx.doi.org/10.1016/j.bbagrm.2011.09.004.

[29] S. Balaban, L.S. Lee, M. Schreuder, A.J. Hoy, Obesity and Cancer Progression: Is There a Role of Fatty Acid Metabolism?, Biomed Res. Int. 2015 (2015) 17. doi:10.1155/2015/274585.

[30] N.M. lyengar, C.A. Hudis, A.J. Dannenberg, Obesity and Cancer: Local and Systemic Mechanisms, Annu. Rev. Med. 66 (2015) 297-309. doi:doi:10.1146/annurev-med-050913-022228.

[31] L. Mauro, G.D. Naimo, E. Ricchio, M.L. Panno, S. Andò, Cross-Talk between Adiponectin and IGF-IR in Breast Cancer, Front. Oncol. 5 (2015) 157. doi:10.3389/fonc.2015.00157.

[32] E. Surmacz, Leptin and Adiponectin: Emerging Therapeutic Targets in Breast Cancer, J. Mammary Gland Biol. Neoplasia. 18 (2013) 321-332. doi:10.1007/s10911-013-9302-8.

[33] K.M. Nieman, I.L. Romero, B. Van Houten, E. Lengyel, Adipose tissue and adipocytes support tumorigenesis and metastasis, Biochim. Biophys. Acta - Mol. Cell Biol. Lipids. 1831 (2013) 1533-1541. doi:http://dx.doi.org/10.1016/j.bbalip.2013.02.010.

[34] G.S. Hotamisligil, D.A. Bernlohr, Metabolic functions of FABPs[mdash]mechanisms and therapeutic implications, Nat Rev Endocrinol. 
11 (2015) 592-605.

doi:10.1038/nrendo.2015.122http://www.nature.com/nrendo/journal/v11/n10/abs/ nrendo.2015.122.html\#supplementary-information.

[35] C. Nieva, M. Marro, N. Santana-Codina, S. Rao, D. Petrov, A. Sierra, The Lipid Phenotype of Breast Cancer Cells Characterized by Raman Microspectroscopy: Towards a Stratification of Malignancy, PLoS One. 7 (2012) e46456. doi:10.1371/journal.pone.0046456.

[36] S. Kim, Y. Lee, J.S. Koo, Differential Expression of Lipid Metabolism-Related Proteins in Different Breast Cancer Subtypes, PLoS One. 10 (2015) e0119473. doi:10.1371/journal.pone.0119473.

[37] A. Merdad, S. Karim, H.-J. Schulten, M. Jayapal, A. Dallol, A. Buhmeida, et al., Transcriptomics profiling study of breast cancer from Kingdom of Saudi Arabia revealed altered expression of Adiponectin and Fatty Acid Binding Protein4: Is lipid metabolism associated with breast cancer?, BMC Genomics. 16 (2015) S11-S11. doi:10.1186/1471-2164-16-s1-s11.

[38] H. Cao, M. Sekiya, M. Erikci, M.F. Burak, J.R. Mayers, A. White, et al., Adipocyte lipid chaperone aP2 is a secreted adipokine regulating hepatic glucose production, Cell Metab. 17 (2013) 768-778. doi:10.1016/j.cmet.2013.04.012.

[39] M.E. Ertunc, J. Sikkeland, F. Fenaroli, G. Griffiths, M.P. Daniels, H. Cao, et al., Secretion of fatty acid binding protein aP2 from adipocytes through a nonclassical pathway in response to adipocyte lipase activity, J. Lipid Res. 56 (2015) 423-434. doi:10.1194/jlr.M055798.

[40] I. Schlottmann, M. Ehrhart-Bornstein, M. Wabitsch, S.R. Bornstein, V. Lamounier-Zepter, Calcium-dependent release of adipocyte fatty acid binding 
protein from human adipocytes, Int J Obes. 38 (2014) 1221-1227. doi:10.1038/ijo.2013.241.

[41] L.E. Wu, D. Samocha-Bonet, P.T. Whitworth, D.J. Fazakerley, N. Turner, T.J. Biden, et al., Identification of fatty acid binding protein 4 as an adipokine that regulates insulin secretion during obesity, Mol. Metab. 3 (2014) 465-473. doi:http://dx.doi.org/10.1016/j.molmet.2014.02.005. 
Figure 1. eFABP4 is internalized by breast cancer cells. MCF-7 and MDA-MB-231 (231) cells were treated with $100 \mathrm{ng} / \mathrm{ml}$ of eFABP4 (eF100). After $24 \mathrm{~h}$, the cells were lysed with $2 \%$ SDS buffer, and western blot (Fig 1a) or immunofluorescence (Fig 1b) was performed. The results are expressed as the mean \pm SEM of three independent experiments. $* * * * \mathrm{P}<0.0001$ and $* * * \mathrm{p}=0.0002$ vs untreated cells. $281 \times 181 \mathrm{~mm}(300 \times 300 \mathrm{DPI})$ 
A

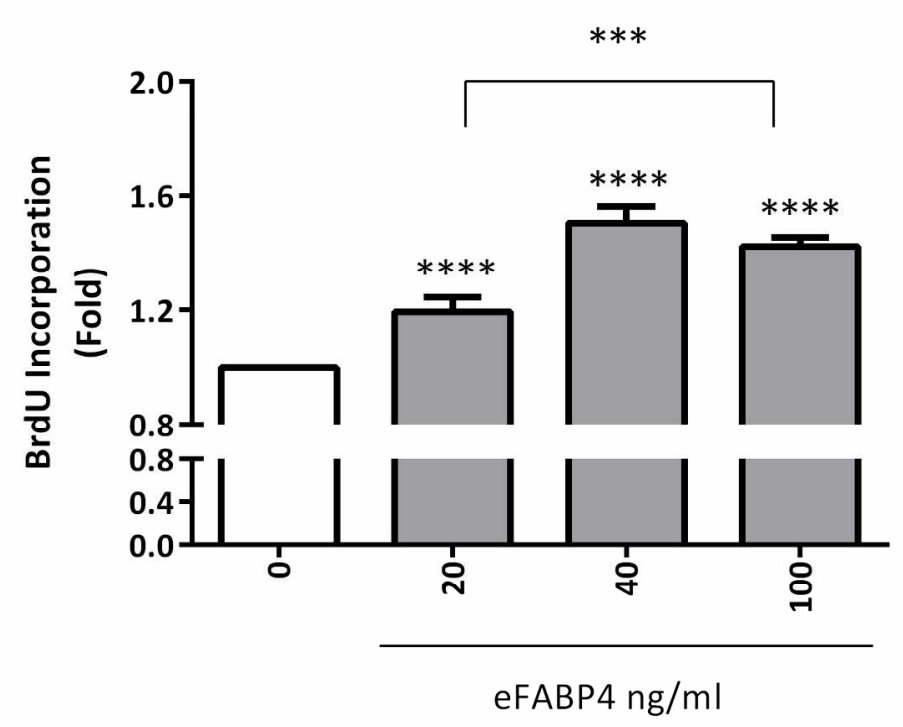

B

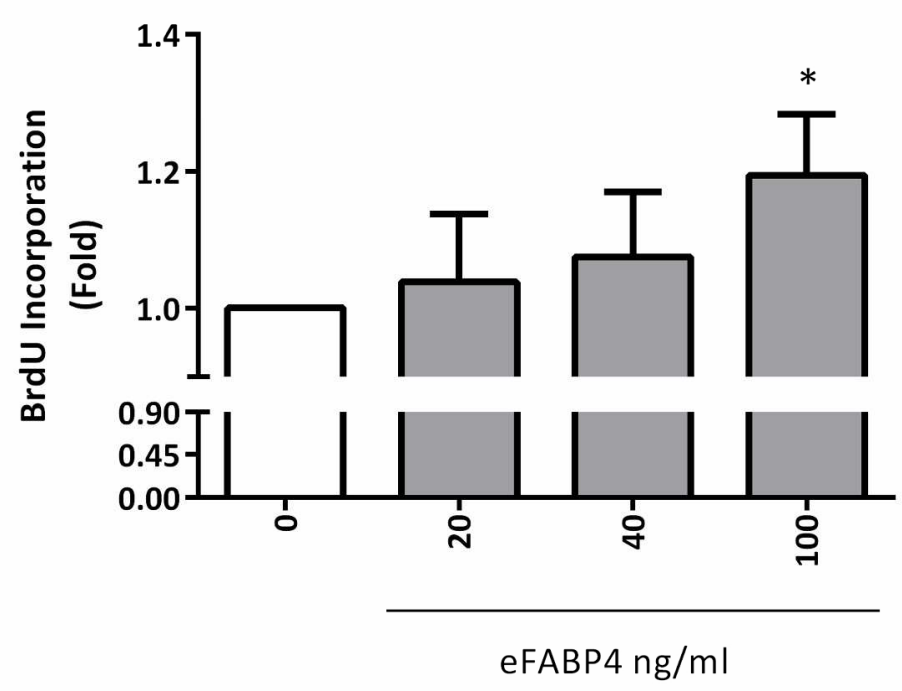

Figure 2. Effect of eFABP4 on the proliferation of breast cancer cells. Effect of eFABP4 $(20-100 \mathrm{ng} / \mathrm{ml})$ on the proliferation of MCF-7 (Fig 2a) and MDA-MB-231 (Fig 2b) cells was assessed by BrdU incorporation. The results are expressed as the mean \pm SEM of three independent experiments run in quintuplicate. $* * * * p<0.0001, * * * p<0.0002$ and $* p=0.0169$ vs untreated cells. $150 \times 215 \mathrm{~mm}(300 \times 300 \mathrm{DPI})$ 


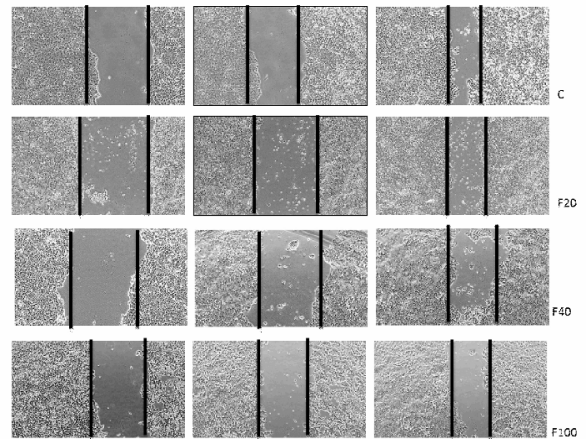

B
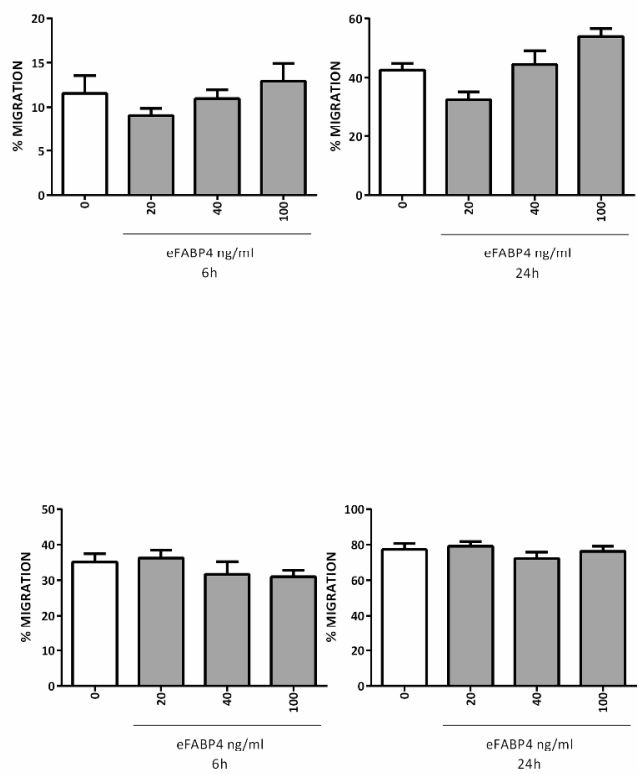

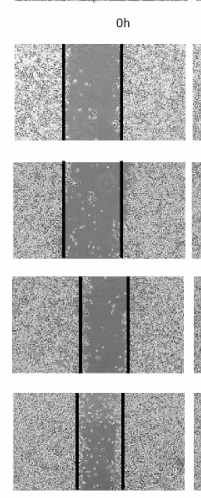

on
$6 \mathrm{~h}$ $24 \mathrm{~h}$
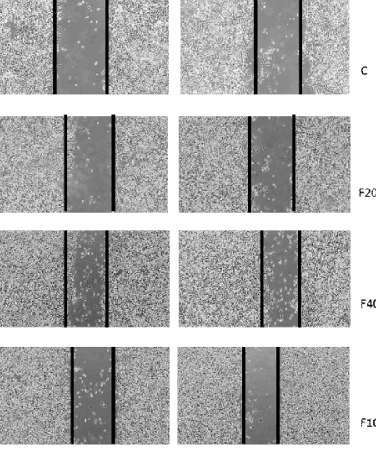

6 h

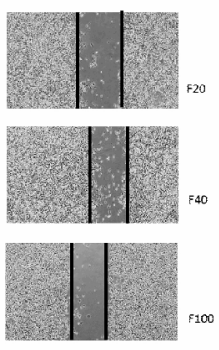

$24 \mathrm{~h}$

Figure 3. Effect of eFABP4 on the migration of breast cancer cells. After reaching confluence, MCF-7 and MDA-MB-231 cells were treated with eFABP4 $(20-100 \mathrm{ng} / \mathrm{ml})$ at different times. A wound-healing assay was performed, and the \% of migration was measured in MCF-7 (Fig 3a) and MDA-MB-231 (Fig 3b) cells. The results are expressed as the mean \pm SEM of three independent experiments run in quintuplicate. $281 \times 215 \mathrm{~mm}(300 \times 300 \mathrm{DPI})$ 
A

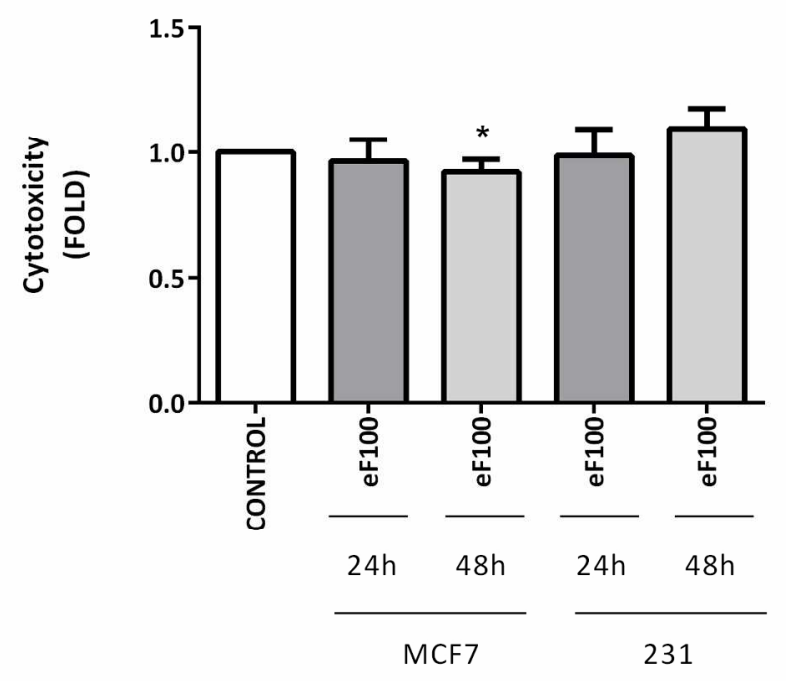

B

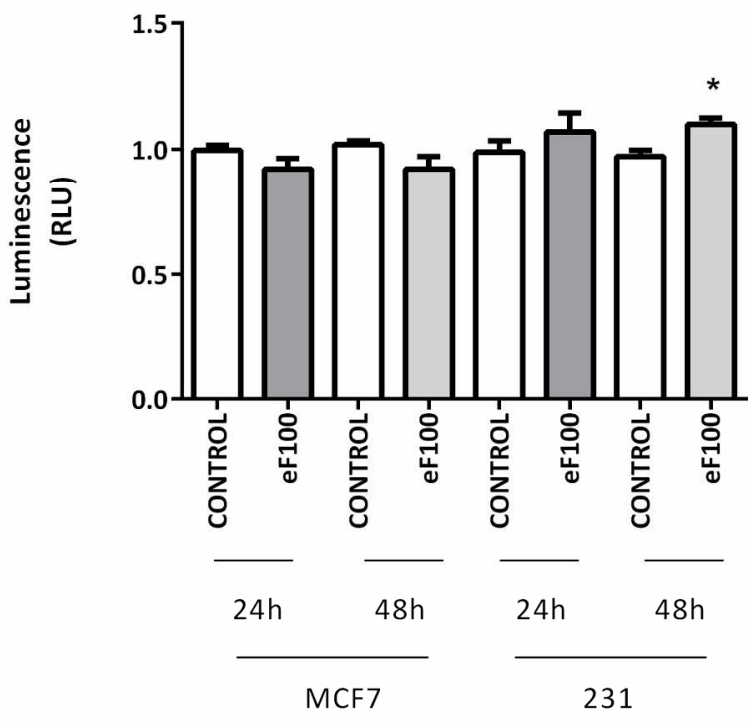

Figure 4. Effect of eFABP4 on cytotoxicity and cell viability of breast cancer cells. Effect of eFABP4 (100 $\mathrm{ng} / \mathrm{ml}$ ) on cytotoxicity was assessed using an LDH detection kit at $24 \mathrm{~h}$ and $48 \mathrm{~h}$. Moreover, the effect of eFABP4 $(100 \mathrm{ng} / \mathrm{ml})$ on cell viability was assessed using the Cell Titer Glo Detection Kit at the same times. Cytotoxicity (Fig 4a) and cell viability (Fig 4b) were measured in MCF-7 and MDA-MB-231 cells. The results are expressed as the mean \pm SEM of three independent experiments run in triplicate $(* p<0.05)$. $121 \times 211 \mathrm{~mm}(300 \times 300 \mathrm{DPI})$ 
A

Figure 5. Effect of eFABP4 on the AKT and MAPK pathways in breast cancer cells. The effect of eFABP4 (100 $\mathrm{ng} / \mathrm{ml}$ ) on the AKT (Fig 5a. MCF-7 left, MDA-MB-231 right) and MAPK (Fig 5b. MCF-7 left, MDA-MB-231 right) pathways was assessed by western blot at short times. Representative western blots and relative densitometric analyses are shown. The results are expressed as the mean \pm SEM of three independent experiments. $* p<0.05$ and $* * p<0.005$ vs. unstimulated cells (control). $181 \times 206 \mathrm{~mm}(300 \times 300$ DPI $)$ 
A

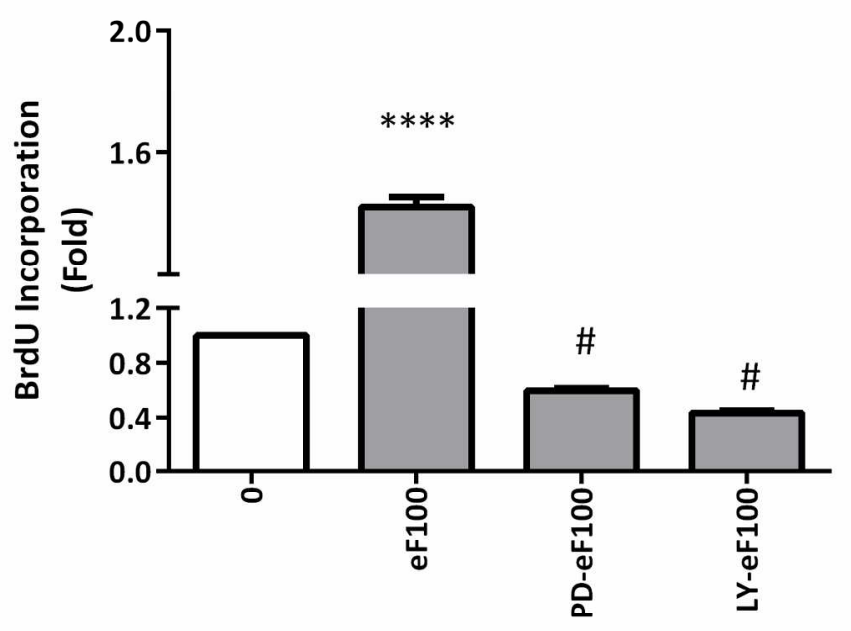

B

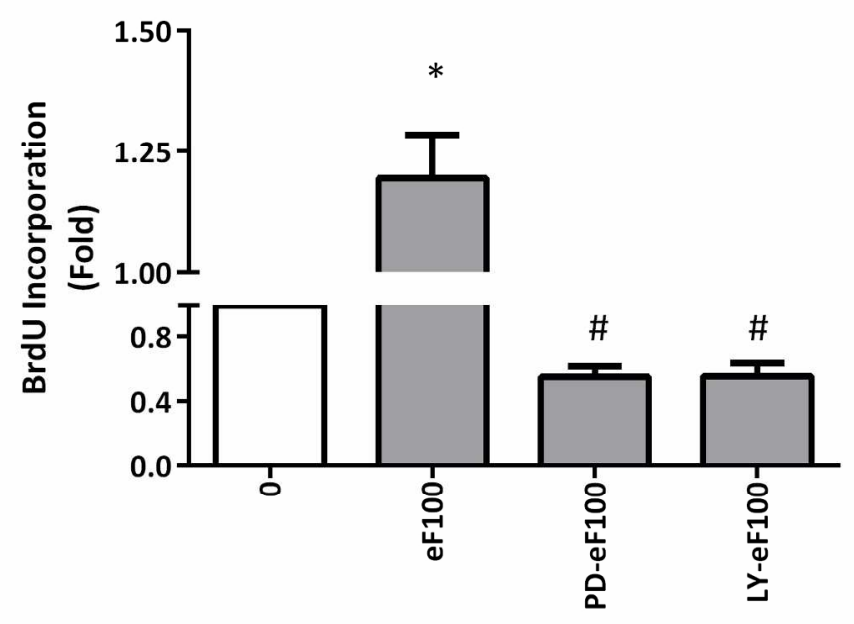

Figure 6. Effect of AKT and MAPK pathway inhibition on eFAPB4 cell proliferation induction in breast cancer cells. AKT (LY-294002, $5 \mu \mathrm{M}$ ) and MAPK (PD98059, $10 \mu \mathrm{M})$ inhibitors were added to breast cancer cells to assess the pathways activated upon eFABP4 $(100 \mathrm{ng} / \mathrm{ml})$ treatment. BrdU incorporation was analysed. The results are expressed as the mean \pm SEM of three independent experiments. $* * * * p<0.0001, * p=0.0169$ and $\# p<0.05$ vs untreated cells. $132 \times 214 \mathrm{~mm}(300 \times 300 \mathrm{DPI})$ 
A
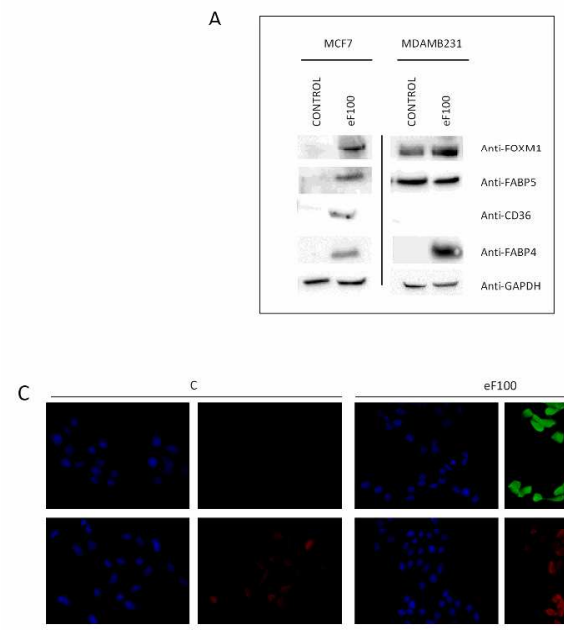

D
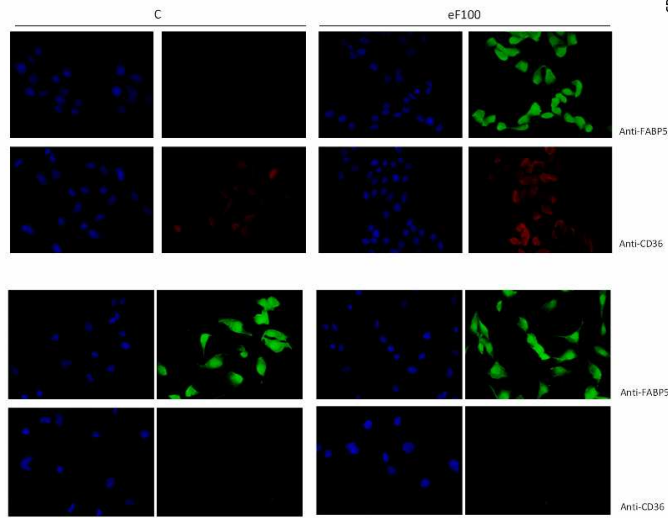
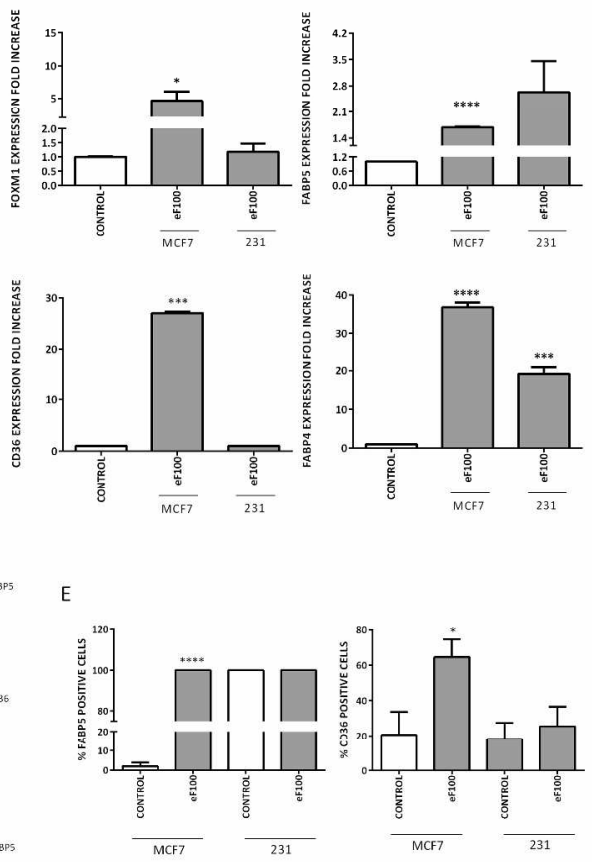

Figure 7. Regulation of the expression of fatty acid transport proteins by eFABP4. MCF-7 and MDA-MB-231 (231) cells were treated with $100 \mathrm{ng} / \mathrm{ml}$ of eFABP4 (eF100). After $24 \mathrm{~h}$, the cells were lysed with $2 \%$ SDS buffer, and western blot (Fig 7a and Fig $7 b ; * * * * p<0.0001, * * * p=0.0001$ and $* p<0.05$ vs untreated cells) or immunofluorescence (Fig 7c-MCF-7 cells, 7d-MDA-MB-231 cells and 7e; ****p<0.0001 and *p<0.05 vs untreated cells) was performed. The results are expressed as the mean \pm SEM of three independent experiments.

$281 \times 217 \mathrm{~mm}(300 \times 300 \mathrm{DPI})$ 